Bond University

Research Repository

\title{
Embedding Environment and Sustainability into Corporate Financial Decision-making
}

Siegrist, Manuel; Bowman, Gary; Mervine, Evelyn M.; Southam, Colette

Published in:

Accounting and Finance

DOI:

10.1111/acfi. 12533

Licence:

Other

Link to output in Bond University research repository.

Recommended citation(APA):

Siegrist, M., Bowman, G., Mervine, E. M., \& Southam, C. (2020). Embedding Environment and Sustainability into Corporate Financial Decision-making. Accounting and Finance, 60(1), 129-147.

https://doi.org/10.1111/acfi.12533

\section{General rights}

Copyright and moral rights for the publications made accessible in the public portal are retained by the authors and/or other copyright owners and it is a condition of accessing publications that users recognise and abide by the legal requirements associated with these rights.

For more information, or if you believe that this document breaches copyright, please contact the Bond University research repository coordinator. 


\title{
Embedding Environment and Sustainability into Corporate Financial Decision-making Manuel Siegrist, Gary Bowman, Evelyn Mervine, Colette Southam*
}

\begin{abstract}
The business case for sustainability can be built upon: (1.) cost reduction from efficient resource utilisation, (2.) revenue enhancement, (3.) risk management, and (4.) intangible assets (Esty and Winston 2009). However, executives often adopt a short-term perspective owing to executive compensation, investor pressure, and decision-making criteria tied to fixed financial reporting systems. We propose an integrated conceptual framework which highlights how firms could embed environment and sustainability into their long-term financial decision-making framework. To give this goal structure, the firm could adopt: (1.) longer-term executive compensation plans, (2.) longer-term financial reporting, and (3.) flexible financial decisionmaking models which embed intangibles.
\end{abstract}

\section{Introduction}

During the late 1980s, when social issues increasingly came into focus, the concept of sustainability gained much attention and the subsequent public pressure led to the exploration of new ways to deal with existing environmental and social problems (Sharma and AragónCorrea 2005). Unsustainable business practices can lead to externalised costs which are borne by the public while excess returns are privatised (Chomsky 2006). Although governments should protect the interests of its citizens, elected officials resist implementing unpopular policies which may translate to lost votes in future elections. (Barbour and Wright 2019). From an organisational perspective, the challenge of sustainability is that social welfare improvements and reduction of environmental impacts must be incorporated into businesses in a way that will not impede economic development (Sharma 2002).

\footnotetext{
* Corresponding author, e-mail: csoutham@bond.edu.au, phone: +61 755952220
} 
From an agency perspective, the firm revolves around the creation of a perpetual legal entity with the overarching goal to maximise shareholder value. In theory, this should require firms to take a long-term view to deliver the required results but in practice, most firms adopt a short-term perspective (Winston 2010; Barton and Wiseman 2015; Terry 2015). There is extensive academic literature demonstrating how executives will act in a short-term manner when offered incentives that reward such behaviour (Demirag 1995; Marginson and McAulay 2008; Marginson et al. 2010). Misaligned compensation systems lead executives to make decisions that are not in line with creating long-term shareholder value (Jensen and Meckling 1976; Laverty 1996; Bushee 1998; Brav et al. 2005; Graham, Harvey, and Rajgopal 2005). There is also a body of academic findings on investor pressure to generate fast, high returns (Demirag 1995; Bhojraj et al. 2009; Ernstberger, Link, and Vogler 2011), contributing to the short-term time horizon of public firms (Zellweger 2007).

From the practitioner viewpoint, Winston (2017) argues widely-used financial decisionmaking criteria are not consistent with the creation of long-term shareholder value because the return component often fails to fully reflect off-balance-sheet intangibles such as brand value, reputation, a social license to operate (SLO), and customer and employeee loyalty. Esty and Winston (2009) build their business case for sustainability on four key value drivers: revenues, intangibles, costs, and risks while our current models focus on costs and benefits that are easier to measure. Investments in environment and sustainability represent significant corporate expenses and off-balance-sheet, intangible assets are difficult to price but can create significant value. Intangible assets comprise an increasing share of a firm's market capitalisation (Ocean Tomo 2017), demonstrating why current financial decision-making models are less effective now than they were in the 1970s.

We believe short-termism is the primary barrier to the adoption of sustainability initiatives. As suggested by Gibson (2006), sustainability assessment would be best designed as an integrative process. (Adger et al. 2003) advocate using a decision-making framework 
where outcomes are based on a thick understanding, spanning across various disciplines to gain legitimacy and eventually produce solutions that are equitable, efficient, and effective. The current paper integrates the academic with the practitioner literature to first characterise the main contributors to short-termism in corporate decision-making. While the academic literature has focused on the agency framework for understanding managerial decision-making, it has seldom identified financial decision-making models such as net present value (NPV) or return on investment (ROI) as causes for the inherent short-termism within firms. In the current article, we integrate this practitioner-identified shortcoming with widely-accepted academic studies to develop a conceptual framework that synthesises them jointly to develop a novel framework that incorporates sustainability to create long-term shareholder value. Esty and Winston's framework highlights the importance of developing new decision-making tools that would capture the economic potential of environment and sustainability investments.

Section 2 will present our research motivations through mapping the business case for embedding environment and sustainability into corporate financial decision-making onto its four underlying value drivers. In Section 3, we will apply an agency framework to categorise and integrate sources that incentivise executives to adopt a short-term perspective which we believe to be a key underlying barrier to adopting sustainability. In Section 4, we will propose an integrated conceptual framework to drive sustainability from which we derive tangible ways firms could embed environment and sustainability into their long-term financial decisionmaking framework.

\section{The Business Case}

Under the premise of value-based management, it is commonly accepted that the primary objective of executives should be to maximise the value of the firm for its shareholders (Boatright 2017; Moyer, McGuigan, and Rao 2017). Citing economic theory, Pigou (1920) 
suggested that the firm should not internalise any negative externalities unless it strictly relates to its shareholding stakeholders. Over the past century, most firms have followed this philosophy and have focused on their core business without addressing societal or environmental concerns.

Nobel laureate Milton Friedman was not opposed to firms engaging in social welfare activities that increase long-term shareholder value (Friedman 1979). This theory is supported by Michael Jensen, who stated '200 years' worth of work in economics and finance indicate that social welfare is maximized when all firms in an economy attempt to maximize their own total firm value' (Jensen 2002). This shareholder approach contrasts with the later-developed stakeholder approach, which seeks to broaden the concept and push it beyond traditional economics (Freeman and McVea 2001). Corporate decision-making becomes more complex when a firm tries to balance acting responsibly with financial performance (Salzmann, IonescuSomers, and Steger 2005).

Sustainability was defined by the World Commission on Environment and Development (WCED) as meeting present needs without compromising the ability of future generations to meet their needs (World Commission on Environment and Development 1987). In 2000, the United Nations Millennium Development Goals communicated a commitment to environmental sustainability which was followed up with the 2015 Sustainable Development Goals. This put environmental sustainability on equal footing with economic development (UN General Assembly 2015).

In the late 1980s, social issues, including life quality and human rights, were at the forefront of the sustainability movement (Sharma and Aragón-Correa 2005), and the term sustainability became associated with the right and wrong-doing of firms. Public pressure pushed for new problem-solving approaches to integrate environmental protection and economic development to alleviate poverty. Firms now faced the challenge of integrating 
corporate economic activities while also focusing on social stakeholders such as employees, supply chain, and the community (Dunphy, Griffiths, and Benn 2003).

From a societal perspective, the lack of sustainable practices might be considered a market failure as it would represent substantial cost to society and therefore represent an implied subsidy, a social grant, or 'legal looting' (Akerlof et al. 1993) since the costs are paid by the public and excess returns are privatised (Chomsky 2006). Carbon markets, which aim to regulate, price, cap and reduce the emissions of Greenhouse Gases (GHGs), are an example of internalising external costs. A study by Linnenluecke, Smith, and Whaley (2017) for the fossil fuel industry quantified the socialised costs of carbon ('looted amount') to be between USD 525 billion to USD 115 trillion for the years 1995 to 2013.

Executives of the firm strive to be at least as profitable as in previous years or, in the bestcase scenario, see profits grow. Dyllick and Hockerts (2002) define 'corporate sustainability' as meeting the needs of a firm's direct and indirect stakeholders without compromising the needs of future stakeholders. This concept encompasses sustainable development, corporate social responsibility (CSR), stakeholder theory, and corporate accountability (Wilson 2003).

Henderson (2015) and Whelan and Fink (2016) state that the business case against sustainability is it may be harmful to a firm's competitiveness. Others have argued environmental sustainability should be handled by the public sector because engaged firms mostly produce 'sophisticated greenwashing at best' (Stavins 2011; Walker and Wan 2012). Executives are often reluctant to implement sustainability strategies because they believe the costs outweigh the economic benefits (Henderson 2015). Earlier studies did not find a causal relationship between sustainable practices and added shareholder value (Hansen, Ibarra, and Peyer 2013; Margolis and Walsh 2003). However, public discourse has changed significantly over the past two decades and has put pressure on firms that have been identified as key contributors to environmental problems resulting in climate change (Walker and Wan 2012). 
Artiach et al. (2010) investigated the main factors driving corporate sustainability performance using a stakeholder framework. Their study found that leaders in this field are most likely the largest firms of the industry, which are under more scrutiny by regulators and stakeholders due to their size. Wood et al. (2006) found stakeholder opinion was a main driver for improving a firm's environmental performance with 42 per cent of the executives voting it as the most important element. These results underpin the findings by Schmidheiny and Zorraqu'n (1996) and Gunningham et al. (1999), proving the effectiveness of market forces as a means to influence investment decision-making of firms and the subsequent effect on both environmental and sustainability performance.

Esty and Winston (2009) built their conceptual case for sustainability in business on four key elements: revenues, intangibles, costs, and risks (Figure 1). They classify revenues and intangibles as the upside components, since these have the potential to create value, while costs and risks are potential downsides which can destroy value if not managed adequately.

Figure 1

The case for sustainability: innovation and value drivers (Esty and Winston 2009)

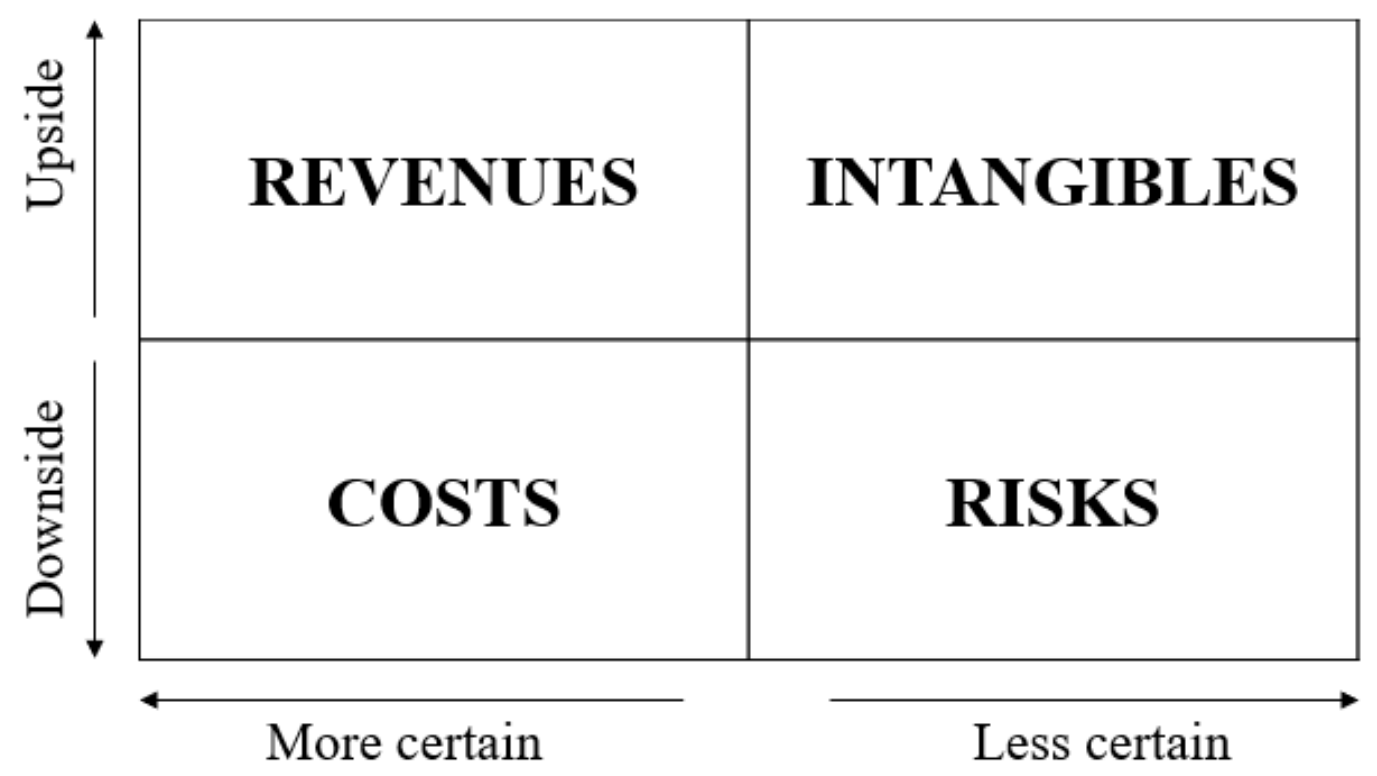

The cost component comprises the ecological footprint of the firm; improving the efficiency of the firm's spending in water, electricity, and waste reduces costs (Winston 2010). 
Empirical data on the cost curve for renewable energy has seen a downward trend over the last decade, with the levelised energy costs per megawatt hour (Mwh) of wind falling by 66 per cent and solar by 85 per cent between 2009 and 2016 (O'Boyle 2017).

The risk component of sustainability includes future regulatory and environmental policy changes, and can also include items related to the reliability and resilience of the supply chain (Winston 2017) which are increasing due to climate change (Linnenluecke et al. 2015). Additionally, workplace safety can reduce downside risk. The 2015 Brazilian Samarco mine disaster killed 19 people (Phillips 2018), destroyed property, and resulted in AUD 55 billion in compensation, clean-up, and renaturation costs (Macalister 2016). BHP Billiton's shares dropped 6 per cent immediately after the disaster and destroyed more than AUD 35 billion in market capitalisation .

With the transformation to a more sustainable economy, the revenue side is gaining momentum as new products and technologies emerge to solve environmental challenges. Additionally, more sustainable products may justify overall higher prices since they have the potential to be advertised under the 'green marketing' concept (Arseculeratne and Yazdanifard 2013). Linnenluecke et al. (2017) estimate the development of cleantech patents will contribute USD 10 to 15 trillion by 2050 while intergovernmental sources estimate up to USD 29 trillion (OECD/IEA and IRENA 2017).

The most complex factor contributing to sustainability-linked value creation is the intangible component which includes reputation, brand value, patents, trademarks and copyrights, and trade secrets. Building brand recognition also influences costs, revenues, and risks because it enables the firm to build long-lasting customer and employee relationships. The Ocean Tomo (2017) Annual Study of Intangible Asset Market Value reveals intangible assets made up only 17 per cent of market capitalisation for S\&P 500 firms in 1975 and has continuously risen to 84 per cent in 2015 . Given this evolution, it is evident there is a need to incorporate this difficult-to-measure but very important value driver (see Figure 2). 


\section{S\&P 500 Market Value Components}

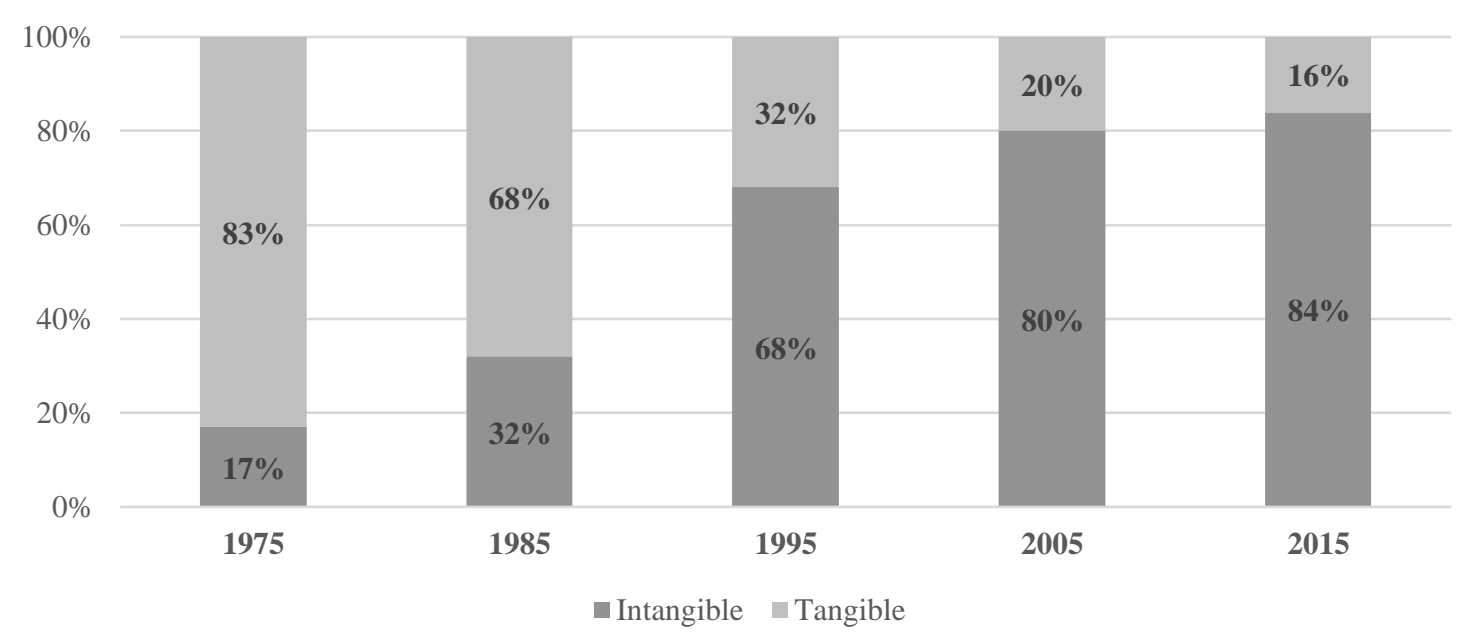

Incorporation of these four value drivers for sustainability saves money, helps make future cash-flows more reliable, drives sales, and helps create long-term, sustainable cash-flows (Winston 2017). Not only does it drive innovation, it also builds a relationship with the (broader) community and can give the firm a SLO (Lacey, Parsons, and Moffat 2012), which has to be earned through their stakeholders including local communities, employees, customers and government.

\section{Short-term Perspective}

The relationship between stockholders and executives of a corporation is a pure agency relationship in which the owner of the firm (shareholder) outsources the task of running the business to a third party: the manager (Jensen and Meckling 1976). This separation of ownership and management results in agency costs, which are defined as the sum of 'monitoring expenditures, bonding expenditures plus the residual loss, which is the total reduction in welfare for the principal as a subsequent result of the divergence from the goals by 
the agent' (Jensen and Meckling 1976). Agency theory reconfirms the importance of incentives and serves as a reminder that within the life of an organisation, most actions are based on selfinterest (Barney and Ouchi 1990). Problems will arise when firms inadvertently create systems which incentivise managers and employees to act in ways that do not maximise shareholder value. One reason why the establishment of the business case for sustainability continues to be difficult is the short-term view taken by most firms (Winston 2010; Barton and Wiseman 2015; Terry 2015), which makes the implementation of a sustainable business model a complex issue.

The literature has also identified many institutional factors that may hinder sustainability integration. Placet et al. (2005) identified inertia as one of the main barriers to sustainability, especially for mature industries, as it promotes the continuation of business the way it has been done in the past. Linnenluecke and Griffiths (2010) investigated the link between sustainability and culture, concluding various subgroups exist among employees each holding different views, values, and perspectives (Martin 2001; Zammuto 2005). It was concluded that while subcultures can provide certain barriers for driving a comprehensive sustainability-related change of culture, integrating key measures of sustainability into employee performance evaluation can help instil the inherent values and beliefs of an organisation (Dunphy, Griffiths, and Benn 2003; Linnenluecke and Griffiths 2010). While it is recognised there are other contributing factors, the scope of this chapter will focus on the underlying causes of short-termism that impacts the firm's executives.

It is also acknowledged alternative theories to agency theory are widely accepted in the sustainability literature. The resource-based view (RBV) emerges as a popular theory with the aim of gaining a competitive, sustainable advantage (Fahy 2000). From an RBV point of view, CSR can be seen as worth pursuing since it supports the development of new resources and capabilities and also improves the firms' reputation and stakeholder relationships (Branco and Rodrigues 2006). According to legitimacy theory, a firm needs to hold a SLO in order to gain 
legitimate access to resources (Deegan 2002) since firms are subject to a greater acceptance by society (Hahn and Kühnen 2013), making the acquisition of an SLO a valuable resource (Dowling and Pfeffer 1975; Ashforth and Gibbs 1990; Suchman 1995). Similar to agency theory, signalling theory (Spence 1978; Connelly et al. 2011) deals with asymmetric information between the firm and its stakeholders. Signalling theory suggests that the firm should proactively reduce information asymmetry through credible sustainability reporting. In doing so, the firm creates a positive media coverage and also secure its legitimacy (Hahn and Kühnen 2013).

A shortcoming of the agency relationship perspective is the agent will focus purely on investing in value-maximising projects when making strategic decisions for the firm. In doing so, the agent is potentially sacrificing better investments that would pay off in the far future, beyond the agents' tenure, for short-term gains (Gibson 2006). This conundrum has been previously described by Laverty (1996) as 'intertemporal choice.' Laverty defined shorttermism as 'decisions and outcomes that pursue a course of action that is best for the short term but suboptimal over the long run' (Laverty 1996). Schumpeter (1942) highlighted problems with only considering the short-term while Loewenstein and Thaler (1989) caution us to consider intertemporal choices in which 'the timing of cost and benefits are spread out over time' in our decision-making models to ensure long-term sustainability for the firm.

Business executives continually make decisions where a choice between a long or shortterm investment needs to be made. (Bansal and DesJardine 2015; Terry 2015). Figure depicts our 'Unsustainable Business Model' model, which demonstrates mechanisms by which the short-term perspective leads to the erosion of long-term shareholder value. Our current financial reporting and communications are the key input and influence executive actions related to three different paths: (1.) executive compensation systems (Jensen and Meckling 1976; Laverty 1996; Bushee 1998; Brav et al. 2005; Graham, Harvey, and Rajgopal 2005), (2.) stock price 
reactions resulting in investor pressure for fast and high returns (Demirag 1995; Bhojraj et al. 2009; Ernstberger, Link, and Vogler 2011), and (3.) financial decision-making models (Winston 2017) which all contribute to the short-term time horizon of public firms (Zellweger 2007).

Figure 3

Unsustainable Business Model (own creation)

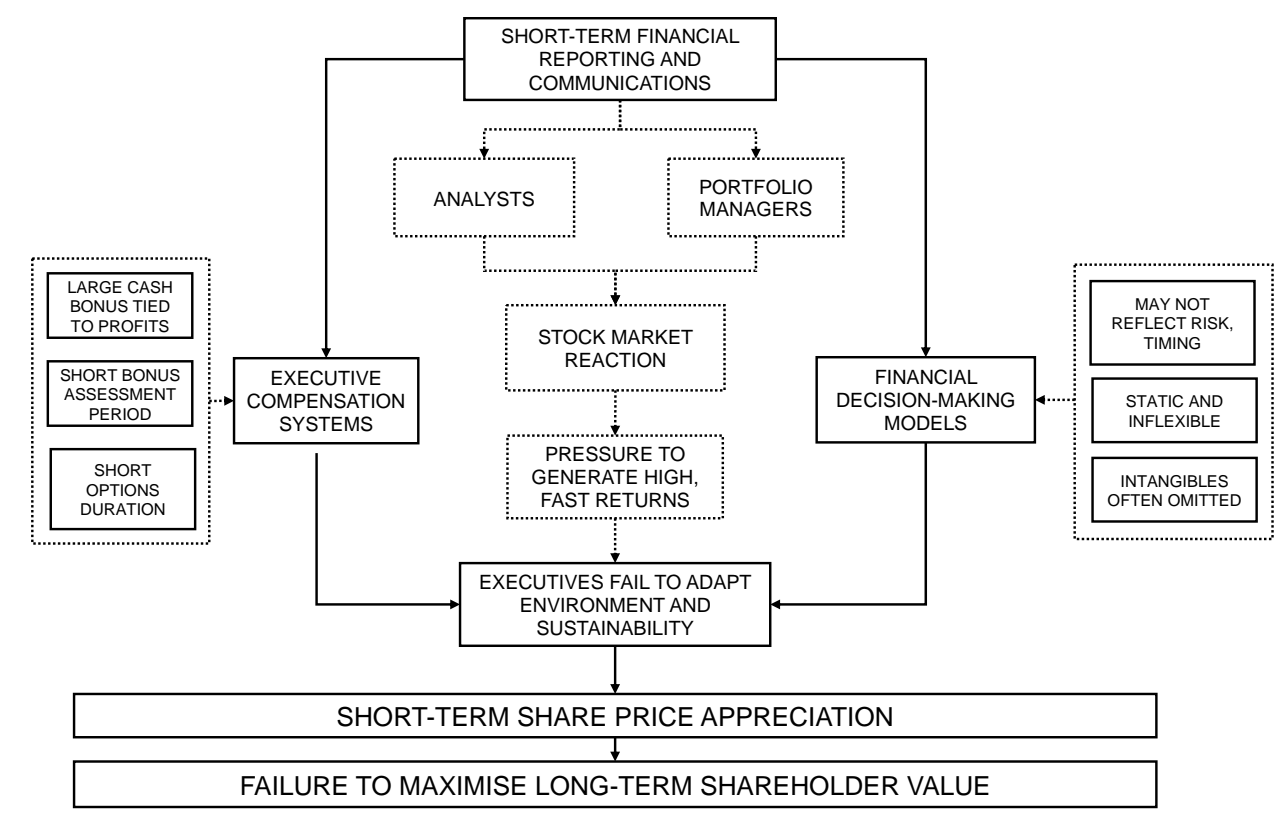

Annual financial reporting influences executives via their compensation systems which are designed to curb agency costs by aligning the goals of the executives with those of the shareholder (Eisenhardt 1989). There is ample research documenting the weak link between executive pay and performance (Ungson and Steers 1984; Pearce, Stevenson, and Perry 1985). Unfortunately, most compensation plans include large cash bonuses based on a single year of performance and 'almost all companies rely on some measure of accounting profits' (Murphy 1999). Giving executives this short assessment period encourages them to make short-term decisions (Cebon and Hermalin 2014). In theory, executive stock options provide the CEO with an incentive to maximise long-term shareholder value by tying their compensation to the share 
price, but Chen (2004) outlines various ways in which the design of option plans can destroy shareholder value and Wyld (2010) suggests that executives 'manipulate the exercise of options to their personal benefit.' The duration for most option plans is short; typically 25 per cent vest annually in each of the four years following the grant (Murphy 1999). Laverty (2004) posits that executives operate within the given framework; therefore, the system is to blame, not the individual, suggesting the need to revise current compensation plans.

The release of quarterly financial reports and earnings announcements fuel analyst recommendations which impact stock market prices and have been identified as the main culprit behind short-term behaviour (Hayes and Abernathy 1983; Dertouzos, Lester, and Solow 1989; Porter 1992; Jacobs 1991; Laverty 1996; Doukas and Switzer 2000). Additionally, Drucker (2011) contends 'the need to satisfy the pension fund manager's quest for higher earnings next quarter... pushes the top executives toward decisions they know to be costly, if not suicidal, mistakes.' In an extensive survey of 400 US financial executives, Graham et al. (2005) report 78 per cent chose to smooth earnings, potentially sacrificing long-term investments due to pressure from financial markets. Similar findings by Bushee (1998), Dechow \& Sloan (1991), Bartov (1993), Penman \& Zhang (2002), and Barton and Wiseman (2015) provide empirical support consistent with managers selling assets, reducing spending on $\mathrm{R} \& \mathrm{D}$, or buying back shares to meet quarterly earnings target at the expense of long-term value creation.

Annual reporting also feeds our current decision-making tools which fail to reflect the full value of the firm's investments in environment and sustainability. While the ROI metric has utility, return is an accounting measure that fails to incorporate both the risk or timing of future payoffs. NPV is based on the discounted cash flow (DCF) model, which is one of the most common models used in the financial world (Brealey, Myers, and Allen 2014; Marchioni and Magni 2018). Only projects with a positive NPV should be undertaken (Moyer, McGuigan, and Rao 2017) since they should create shareholder value (Brav et al. 2005). However, most investment projects take place in a highly flexible environment, and Dixit and Pindyck (1994) 
showed the static NPV model ignores inherent project flexibility. Neither ROI nor NPV fully encompass the value of the investment since intangible off-balance sheet assets are not included. Further, inflated cost of capital rates, as well as short investment time frames, further fuel the short-term perspective and render sustainable, long-term investments less likely (Dobbs 2009).

Subsequently, finance and accounting systems of firms globally are set up to focus on the management of short-term costing, reporting, and disclosure rather than capturing the possible long-term values (Linnenluecke et al. 2015). Since an investment decision may take several years to reveal its true value, the timing of dealing with these trade-offs as well as the tools utilised to make said decision become apparent and are central to the notion of sustainability (Laverty 1996). Investments in research and development (R\&D) and other intangible expenses such as human capital and corporate culture also require a long-term view (Henderson 2015). Since the cost of investments is borne in the present, executives are tempted to forgo long-term returns for short-term results (Terry 2015). In quantifying the macro impact of short-termism, Terry (2015) concluded the pressure to deliver short-term results every quarter cuts US growth by about 0.1 percentage points per annum.

\section{Driving Sustainability}

To challenge the status quo and launch sustainable business practices with a positive return, a long-term scope is necessary (Tushman and Romanelli 1985; Christensen 2014). In order to capture long-term value accordingly, reporting and accounting systems need to be set up as they play an integral part of both strategy and risk management (West and Berereton 2013). Hollindale et al. (2019) highlight the importance of integrating high-quality disclosure of GHG emission and reporting which integrates both financial and sustainability performance (Dumay et al. 2016), has been promoted as a solution to the shortcomings of financial reporting 
(Linnenluecke et al. 2015). Unfortunately, a recent study reports that less than a third of mainstream global equity market participants are positive about the 'decision usefulness of integrated reporting and its relevance to them' and raised concerns about lack of comparability and consistency with the framework (Slack and Tsalavoutas 2018). Further, participants in the Pilot Programme Business Network of the International Integrated Reporting Council state integrated reporting is not relevant to analysts as the reports do not provide the information required by analysts in sufficient detail or preferred format (Abhayawansa, Elijido-Ten, and Dumay 2019).

Although early work on business models focused on economic value creation, more recently, the literature has identified business models as a core component in embedding sustainability into organisations and relates to how the firm translates strategy into activities (Bocken et al. 2014). This sustainable business model innovation framework embodies the process of transforming business models in order to balance economic, social, and environmental concerns (Schaltegger, Lüdeke-Freund, and Hansen 2012). Mitchell, Curtis, and Davidson (2007) advocate that firms that extend to a triple bottom line (social, ecological, and economic) will continue to operate in the long run. However, per the triple bottom line, framework is missing an interconnection of the three pillars (Elkington 1998). Gibson (2006) argues these sustainability frameworks fail to deliver the expected outcomes and he advocates a more integrative approach rather than trading off and balancing the needs of various stakeholders.

The model below (Figure ) depicts changes to executive compensation, financial reporting, and decision-making models which could support the creation of long-term, sustainable shareholder value. 


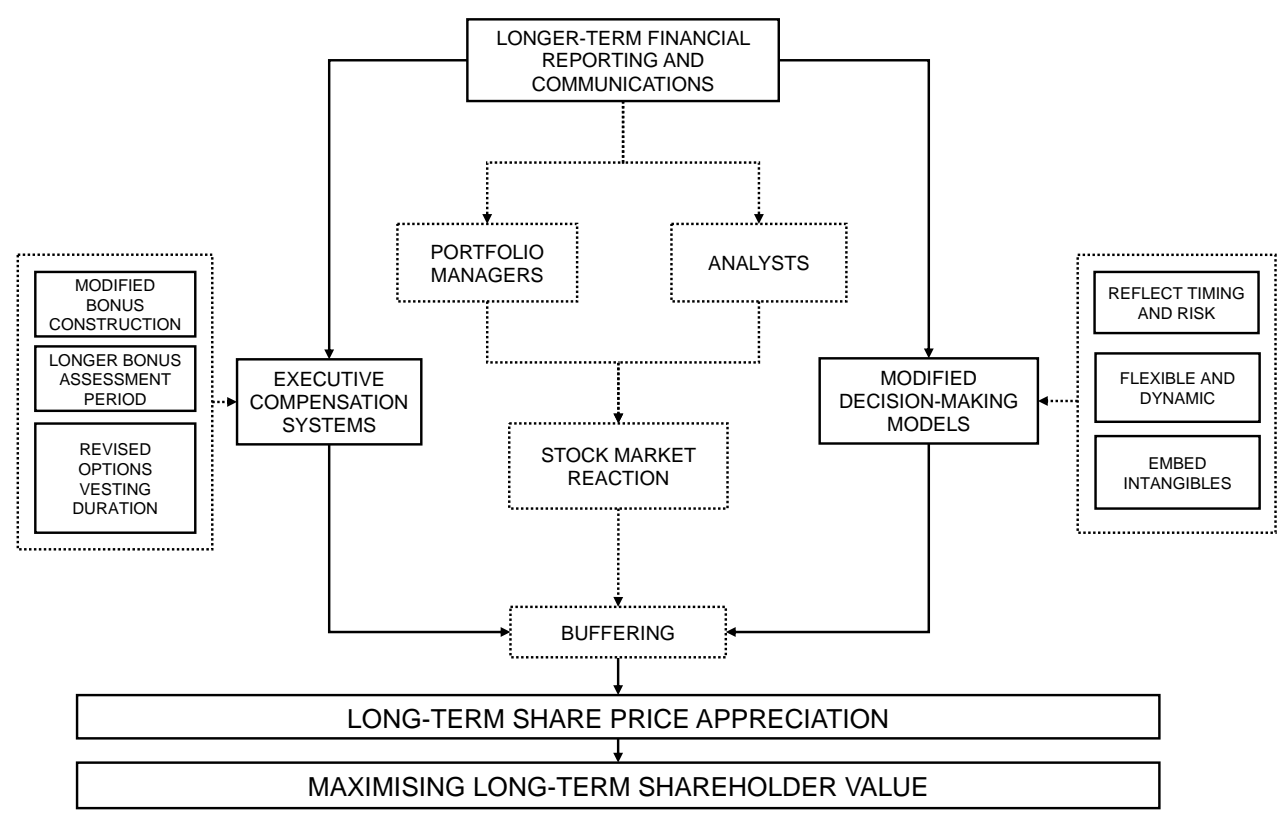

First of all, executive compensation systems could be decoupled from considering only last year's accounting figures. Pozen (2014) suggests extending the one-year assessment period for management incentive systems to three to five years to reduce short-termism. The structure of executive compensation plans is very similar across firms, but firms could diverge from the pack and link the bonus to longer-term measures. Additionally, executive stock options design could tie vesting to measures other than simply the passage of time. Gopalan (2014) developed a novel measure of executive pay duration in an attempt to quantify the extent to which executive compensation is short-term which represents a promising first step in developing optimal compensation structures.

Secondly, firms could eliminate quarterly reporting to encourage organisations to focus on the long-run. Unilever CEO Paul Polman opted to cease quarterly reporting, shunning shareholders that do not buy into the long-term, value-creation model which offers equitability, sustainability, and shared values (Boynton 2015). This view is reinforced by Warren Buffet (Berkshire Hathaway) and Jamie Dimon (JP Morgan Chase). As shown in the 'sustainable 
business model,' longer-term financial reporting would act as a buffer between the stock market reaction and the firm and thus enable a long-term view and subsequent adoption of environment and sustainability.

Thirdly, firms must rely on modified decision-making models. Firms need to move away from ROI, which fails to consider the timing and risk of the cashflows, and focus entirely on short-term profit maximisation. In order to overcome the lack of flexibility of the NPV model, Dixit and Pindyck (1994) proposed the use of real options models, which more realistically model how managers make decisions as it captures the inherent value in the managers' flexibility to invest, abandon, grow, or shut down a project in response to new information (Moyer, McGuigan, and Rao 2017). These models have the potential to uncover the hidden value of longer-term investments and can help firms better understand and capitalise on uncertainty (Chung et al. 2013). Firms must seek decision models that can adequately quantify the intangible values of an investment, given it is the most important constituent of market capitalisation for today's firms. Revamping the decision-making instruments could be done in various ways. Ulrich and Smallwood (2005) suggest a new metric for human resources, 'Return on Intangibles,' which would incentivise organisations to take actions that create sustainable, intangible value.

If a firm chooses to adopt the sustainable business model on a longer timescale, it would reinforce resilience, reduce risk, increase sales, and improve brand value and create a corporate culture that attracts human capital. Having pilot firms with sustainable goals on their agenda and leading the trend towards sustainability around the globe set a benchmark for the competition and act as a call-to-action. With customer appreciation of said practices, the 'green marketing' effect can give a firm a competitive advantage which the competition cannot ignore over the long run (Arseculeratne and Yazdanifard 2013). This would help to move the market in the right direction as the cost curve for sustainable technologies and strategies is driven downwards. Examples of leaders in the field are manifold: Google, Wal-Mart, Apple, 
Facebook, and others have committed to power their direct energy usage from 100 per cent renewable source (Gade 2017). In 2013, Microsoft was a pioneer in assigning an internal price on their carbon emission which resulted in the reduction of 9.6 million tonnes of $\mathrm{CO}_{2}$ and has inspired 1,200 firms to follow suit (Microsoft 2018).

Institutional investors have expressed their support for environmental, social, and governance (Ernst \& Young 2017). The movement gained further traction in 2016 when Larry Fink, the CEO of BlackRock, the world's largest hedge fund, sent a memo to fellow CEOs advising them to focus more on long-term value creation. The most recent letter (Fink 2018) highlights Blackrock's focus on firms that drive sustainable, long-term growth. He further noted, 'a company's ability to manage environmental, social and governance matters demonstrates the leadership and good governance that is so essential to sustainable growth, which is why we are increasingly integrating these issues into our investment process' .

\section{Conclusions}

This study proposes an integrated conceptual framework highlighting how firms could embed environment and sustainability into their long-term financial decision-making. From a practitioner's viewpoint, Esty and Winston (2009) propose a business case for sustainability that highlights the current focus on revenue, cost, and risk management that largely ignores intangible resources as a value-driver. Given that intangibles make up the majority of today's corporate market capitalisation, firms should not continue to base financial decisions on tools from the 1970s. The recent failure of governments to provide sustainability and environmental solutions has seen society looking to business to address societal issues. Today's public holds firms to more exacting standards with greater expectations of the firms they work for, buy from, and invest in.

We have explicitly applied an agency framework to understand the underlying motivations for executive short-term decision-making. This led us to identify and categorise 
three key input factors fuelling short-term behaviour. Compensation packages designed to curb agency costs often incentivise executives to sacrifice sustainable investments with longer time horizons. Similarly, pressure to meet investor demand for fast and high returns discourages executive investments in sustainability in order to protect short-term earnings. Inflexible and outdated financial decision-making models do not account for the full value of intangible resources and may even fail to adequately price the risk and timing of the cash flows. Overarching, short-term financial reporting and communications strategy drive all these.

While many existing models identify potential barriers to embedding sustainability and environment, our study focuses solely on understanding executive short-termism as a rationale for firms' failure to adopt sustainabilty. Executives often make intertemporal choices that can undervalue, overlook, or intentionally ignore the true potential of the investments and create an imbalance that poses a threat to a firm's long-term sustainability (Bansal and DesJardine 2014). There is an extensive academic literature on investor pressure and compensation as causes for executive short-termism, but by integrating a practitioner viewpoint, we highlight how decision-making models may be a key and often overlooked culprit. Gibson's (2006) critique of the triple bottom line is that it leads to frequent trade-offs because it considers the economic, environmental and social levels individually and not in an integrative manner, whereby our study brings together the academic and practitioner viewpoints to yield an integrative model, of the underlying causes of executive short-term behaviour that results in the unsustainable business model.

Our conceptual framework highlights three ways in which firms could encourage executives to adopt a longer-term perspective and therefore embed more environment and sustainability into their financial decision-making. Executive compensation plans with extended assessment and duration periods with an adjusted compensation mix would create goal congruence between the executives and their shareholders' long-term interests. Rethinking financial reporting to include a longer-term perspective would counteract the constant investor 
demand to produce short-term earnings. Modifying current financial decision-making models to embed intangibles, adjust for risk and timing of investments, and include real options could help reveal the true value of investment-decisions.

This paper highlights the need for revised decision-making tools to address the shorttermism inherent in firms which has pedogocial implications. Despite the headway that has been made with real options over the past two decades, our introductory and MBA finance courses continue to teach the same financial decision-making models,. This paper also stresses the need to capture intangible resources into our financial reporting and models in order to create sustainable, long-term shareholder value. Future studies could involve empirically testing the hypothesis that embedding modified decision-making tools is beneficial for the longterm creation of shareholder value.

On the practical side, this paper proposes three primary areas which firms can focus on to move toward long-term, value-creation. Firms can alter executive compensation systems to lengthen the assessment and duration periods and alter the compensation mix to truly align the goals of the executives with the goals of the firm. Firms can move away from quarterly reporting and be open to alternatives to the current annual financial reporting systems which would allow the firm to concentrate on long-term rather than short-term investors. Furthermore, we recommend modified decision-making models that take real options into account, value intangibles that may currently be omitted, and adequately adjust for time and risk. This would increase investment into environmental and sustainable projects whose outcomes could create novel technologies to further improve natural resource utilisation. 


\section{References}

Abhayawansa, S., E. Elijido-Ten, and J. Dumay, 2019, A practice theoretical analysis of the irrelevance of integrated reporting to mainstream sell-side analysts, Accounting and Finance (early view).

Adger, W. N., K. Brown, J. Fairbrass, A. Jordan, J. Paavola, S. Rosendo, and G. Seyfang, 2003, Governance for sustainability: towards a 'thick' analysis of environmental decisionmaking, Environment and Planning 35, 1095-1110.

Akerlof, G., P. Romer, R. Hall, and G. Mankiw, 1993, Looting: The Economic Underworld of Bankruptcy for Profit, Brookings Papers on Economic Activity, 1-73.

Arseculeratne, D., and R. Yazdanifard, 2013, How Green Marketing Can Create a Sustainable Competitive Advantage for a Business, International Business Research 7.

Artiach, T., D. Lee, D. Nelson, and J. Walker, 2010, The determinants of corporate sustainability performance, Accounting and Finance 50, 31-51.

Ashforth, B. E., and B. W. Gibbs, 1990, The double-edge of organizational legitimation, Organization Science 1, 177-194.

Bansal, P., and M. DesJardine, 2014, Business sustainability, Strategic Organization 12, 70 78.

- 2015, Don't confuse sustainability with CSR, Ivey Business Journal, 1-3.

Barbour, C., and G. C. Wright, 2019, Keeping the republic: Power and citizenship in American politics (CQ Press, Thousand Oaks, California).

Barney, J. B., and W. Ouchi, 1990, Organizational Economics (Jossey-Bass, San Francisco).

Barton, D., and M. Wiseman, 2015, The cost of confusing shareholder value and short-term profit, FT.com (The Financial Times Limited, London).

Bartov, E., 1993, The Timing of Asset Sales and Earnings Manipulation, The Accounting Review 68, 840-855.

Bhojraj, S., P. Hribar, M. Picconi, and J. McInnis, 2009, Making Sense of Cents: An Examination of Firms That Marginally Miss or Beat Analyst Forecasts, Journal of Finance 64, 2361-2388.

Boatright, J. R., 2017, The Corporate Objective after eBay v. Newmark, Business and Society Review 122, 51.

Bocken, N. M., S. W. Short, P. Rana, and S. Evans, 2014, A literature and practice review to develop sustainable business model archetypes, Journal of Cleaner Production 65, 4256.

Boynton, A., 2015, Unilever's Paul Polman: CEOs Can't Be 'Slaves' To Shareholders, Forbes $1-5$.

Branco, M. C., and L. L. Rodrigues, 2006, Corporate social responsibility and resource-based perspectives, Journal of Business Ethics 69, 111-132.

Brav, A., J. R. Graham, C. R. Harvey, and R. Michaely, 2005, Payout policy in the 21st century, Journal of Financial Economics 77, 483-527.

Brealey, R. A., S. C. Myers, and F. Allen, 2014, Principles of Corporate Finance (McGrawHill Education, Maidenhead).

Bushee, B. J., 1998, The Influence of Institutional Investors on Myopic R\&D Investment Behavior, The Accounting Review 73, 305-333.

Cebon, P., and B. E. Hermalin, 2014, When less is more: The benefits of limits on executive pay, The Review of Financial Studies 28, 1667-1700.

Chen, M. A., 2004, Executive Option Repricing, Incentives, and Retention, Journal of Finance 59, 1167-1199. 
Chomsky, N., 2006, Failed states: the abuse of power and the assault on democracy (Allen \& Unwin, Crows Nest, N.S.W.).

Christensen, C., 2014, The innovator's dilemma, Bloomberg Businessweek, 44.

Chung, C. C., S.-H. Lee, P. W. Beamish, C. Southam, and D. Nam, 2013, Pitting Real Options Theory against Risk Diversification Theory: International Diversification and Joint Ownership Control in Economic Crisis, Journal of World Business 48, 122-136.

Connelly, B. L., S. T. Certo, R. D. Ireland, and C. R. Reutzel, 2011, Signaling theory: A review and assessment, Journal of Management 37, 39-67.

Deegan, C., 2002, Introduction: the legitimising effect of social and environmental disclosuresa theoretical foundation, Accounting, Auditing and Accountability Journal 15, 282-311.

Demirag, I., 1995, Short-term performance pressures: is there a consensus view?, The European Journal of Finance 1, 41-56.

Dertouzos, M. L., R. K. Lester, and R. M. Solow, 1989, Made in America (MIT Press, Cambridge, Mass. ).

Dixit, A. K., and R. S. Pindyck, 1994, Investment under uncertainty (Princeton Univ. Press, Princeton, $\mathrm{NJ}$ ).

Dobbs, I. M., 2009, How bad can short termism be?-A study of the consequences of high hurdle discount rates and low payback thresholds, Management Accounting Research 20, 117-128.

Doukas, J., and L. N. Switzer, 2000, Common stock returns and international listing announcements: Conditional tests of the mild segmentation hypothesis, Journal of Banking and Finance 24, 471-502.

Dowling, J., and J. Pfeffer, 1975, Organizational legitimacy: Social values and organizational behavior, Pacific Sociological review 18, 122-136.

Drucker, P. F., 2011, Managing for the Future (Routledge, London).

Dumay, J., C. Bernardi, J. Guthrie, and P. Demartini, 2016, Integrated reporting: A structured literature review, Accounting Forum 40, 166-185.

Dunphy, D., A. Griffiths, and S. Benn, 2003, Organizational change for corporate sustainability (Routledge, London).

Dyllick, T., and K. Hockerts, 2002, Beyond the business case for corporate sustainability, Business Strategy and the Environment 11, 130-141.

Eisenhardt, K. M., 1989, Agency theory, The Academy of Management Review 14, 57-74.

Elkington, J., 1998, Cannibals with Forks : the Triple Bottom Line of 21st Century Business (John Wiley \& Sons, Ltd, Gabriola Island).

Ernst \& Young, 2017, Is your nonfinancial performance revealing the true value of your business to investors?

Ernstberger, J., B. Link, and O. Vogler, 2011, The real business effects of quarterly reporting, Ruhr-Universität Bochum, Arbeitspapier.

Esty, D. C., and A. S. Winston, 2009, Green to gold: how smart companies use environmental strategy to innovate, create value, and build competitive advantage (Wiley, Hoboken, N.J).

Fahy, J., 2000, The resource-based view of the firm: some stumbling-blocks on the road to understanding sustainable competitive advantage, Journal of European Industrial Training 24, 94-104.

Fink, L. D., A Sense of Purpose, available from https://www.blackrock.com/corporate/investorrelations/larry-fink-ceo-letter

Freeman, R. E. E., and J. McVea, 2001, A Stakeholder Approach to Strategic Management McVea, Darden Business School.

Friedman, M., 1979, The social responsibility of business is to increase its profits, 191-197. 
Gade, M., Fortune 500 Companies Accelerating Renewable Energy, Energy Efficiency Efforts, available from https://www.worldwildlife.org/press-releases/report-fortune-500companies-accelerating-renewable-energy-energy-efficiency-efforts

Gibson, R. B., 2006, Beyond the pillars: sustainability assessment as a framework for effective integration of social, economic and ecological considerations in significant decisionmaking, Journal of Environmental Assessment Policy and Management 8, 259-280.

Gopalan, R., T. Milbourn, F. Song, and A. V. Thakor, 2014, Duration of Executive Compensation, Journal of Finance 69, 2777-2817.

Graham, J. R., C. R. Harvey, and S. Rajgopal, 2005, The economic implications of corporate financial reporting, Journal of Accounting and Economics 40, 3-73.

Gunningham, N., M. Phillipson, and P. Grabosky, 1999, Harnessing third parties as surrogate regulators: achieving environmental outcomes by alternative means, Business Strategy and the Environment 8, 211-224.

Hahn, R., and M. Kühnen, 2013, Determinants of sustainability reporting: a review of results, trends, theory, and opportunities in an expanding field of research, Journal of Cleaner Production 59, 5-21.

Hansen, M., H. Ibarra, and U. Peyer, 2013, The best-performing CEOs in the world, Harvard Business Review (Harvard Business School Press, Boston) 81.

Hayes, R. H., and W. J. Abernathy, 1983, Managing our way to economic decline, 522-541.

Henderson, R., 2015, Making the Business Case for Environmental Sustainability, Harvard Business School.

Hollindale, J., P. Kent, J. Routledge, and L. Chapple, 2019, Women on boards and greenhouse gas emission disclosures, Accounting and Finance 59, 277-308.

Jacobs, M. T., 1991, Short-term America (Harvard Business School Press, Boston, Mass).

Jensen, M., 2002, Value Maximization, Stakeholder Theory, and the Corporate Objective Function, Business Ethics Quarterly 12, 235-256.

Jensen, M., and W. H. Meckling, 1976, Theory of the firm: Managerial behavior, agency costs and ownership structure, Journal of Financial Economics 3, 305-360.

Lacey, J., R. Parsons, and K. Moffat, 2012, Exploring the concept of a Social Licence to Operate in the Australian minerals industry: Results from interviews with industry representatives, EP125553, CSIRO, October.

Laverty, K. J., 1996, Economic "Short-Termism": The Debate, the Unresolved Issues, and the Implications for Management Practice and Research, Academy of Management Review 21, 825-860.

, 2004, Managerial myopia or systemic short-termism?: The importance of managerial systems in valuing the long term, Management Decision 42, 949-962.

Linnenluecke, M., J. Birt, A. Griffiths, and K. Walsh, 2015, The role of accounting in supporting adaptation to climate change, Accounting and Finance 55, 607-625.

Linnenluecke, M., and A. Griffiths, 2010, Corporate sustainability and organizational culture, Journal of World Business 45, 357-366.

Linnenluecke, M., J. Han, Z. Pan, and T. Smith, 2017, How markets will drive the transition to a low carbon economy, Economic Modelling 77, 9.

Linnenluecke, M., T. Smith, and R. E. Whaley, 2017, Legal Looting in the Fossil Fuel Industry.

Loewenstein, G., and R. H. Thaler, 1989, Anomalies: Intertemporal Choice, Journal of Economic Perspectives 3, 181-193.

Macalister, T., 2016, BHP Billiton faces £30bn compensation claim over Brazil dam disaster, The Guardian.

Marchioni, A., and C. A. Magni, 2018, Investment decisions and sensitivity analysis: NPVconsistency of rates of return, European Journal of Operational Research 268, 361372. 
Marginson, D., and L. McAulay, 2008, Exploring the debate on short-termism: a theoretical and empirical analysis, Strategic Management Journal 29, 273-292.

Marginson, D., L. McAulay, M. Roush, and T. Van Zijl, 2010, Performance measures and shorttermism: An exploratory study, Accounting and Business Research 40, 353-370.

Margolis, J., and J. Walsh, 2003, Misery Loves Companies: Rethinking Social Initiatives by Business, Administrative Science Quarterly 48, 268-305.

Martin, J., 2001, Organizational culture: Mapping the terrain (Sage publications.

Microsoft, Enabling a more sustainable future, available from https://www.microsoft.com/enus/environment/carbon/our-approach

Mitchell, M., A. Curtis, and P. Davidson, 2007, Can the 'triple bottom line' concept help organisations respond to sustainability issues? (Thurgoona, Australia: Charles Sturt University.

Moyer, R. C., J. R. McGuigan, and R. P. Rao, 2017, Contemporary financial management (Cengage Learning, Stamford, CT).

Murphy, K., 1999, Executive compensation (Marshall School of Business, University of Southern California.

O'Boyle, M., 2017, Wind and Solar Are Our Cheapest Electricity Generation Sources. Now What Do We Do? Green Tech Media, January.

Ocean Tomo, 2017, Intangible asset market value study. https://www.oceantomo.com/intangible-asset-market-value-study/

OECD/IEA, and IRENA, 2017, Perspectives for the Energy Transition: Investment needs for a low carbon energy system.

Pearce, J. L., W. B. Stevenson, and J. L. Perry, 1985, Managerial Compensation Based on Organizational Performance: A Time Series Analysis of the Effects of Merit Pay, The Academy of Management Journal 28, 261-278.

Penman, S. H., and X.-J. Zhang, 2002, Accounting Conservatism, the Quality of Earnings, and Stock Returns, The Accounting Review 77, 237-264.

Phillips, D., 2018, Brazil dam disaster: firm knew of potential impact months in advance, The Guardian.

Pigou, A., 1920, The Economics of Welfare (Taylor and Francis, Cambridge).

Placet, M., R. Anderson, and K. M. Fowler, 2005, Strategies for Sustainability, ResearchTechnology Management 48, 32-41.

Porter, M., 1992, Capital Disadvantage: America's Failing Capital Investment System, Harvard Business Review, 70, September.

Pozen, R., 2014, Curbing short-termism in corporate America, Corporate Board 35, 16.

Salzmann, O., A. Ionescu-Somers, and U. Steger, 2005, The business case for corporate sustainability:: literature review and research options, European Management Journal, 23, 27-36.

Schaltegger, S., F. Lüdeke-Freund, and E. G. Hansen, 2012, Business cases for sustainability: the role of business model innovation for corporate sustainability, International Journal of Innovation and Sustainable Development 6, 95-119.

Schmidheiny, S., and F. Zorraqu'n, 1996, Financing Change: The Financial Community, Ecoefficiency, and Sustainable Development (The MIT Press, Cambridge, MA).

Schumpeter, J. A., 1942, Capitalism, socialism, and democracy (Harper \& Brothers, New York ).

Sharma, S., 2002, Research in Corporate Sustainability: What Really Matters?, Research in corporate sustainability: The evolving theory and practice of organizations in the natural environment. pp. 1-29 1-29.

Sharma, S., and J. A. Aragón-Correa, 2005, Corporate environmental strategy and competitive advantage: a review from the past to the future (Edward Elgar Publishing, London,). 
Slack, R., and I. Tsalavoutas, 2018, Integrated reporting decision usefulness: Mainstream equity market views, Accounting Forum 42, 184-198.

Sloan, R. G., and P. M. Dechow, 1991, Executive incentives and the horizon problem: An empirical investigation, Journal of Accounting and Economics 14, 51-89.

Spence, M., 1978, Job market signaling, Uncertainty in Economics (Academic Press, 281-306.

Stavins, R., 2011, The Problem of the Commons: Still Unsettled after 100 Years, The American Economic Review 101, 81-108.

Suchman, M. C., 1995, Managing legitimacy: Strategic and institutional approaches, Academy of Management Review 20, 571-610.

Terry, S. J., 2015, The macro impact of short-termism, SIEPR discussion paper (Stanford Inst. for Economic Policy Research, Stanford, Calif).

Tushman, M., and E. Romanelli, 1985, Organizational Evolution: A Metamorphosis Model of Convergence and Reorientation, Research in Organizational Behavior: An Annual Series of Analytical Essays and Critical Reviews. Volume 7. 1985, pp. 171-222 (JAI Press, 171-222.

Ulrich, D., and N. Smallwood, 2005, HR's new ROI: Return on intangibles, Human Resource Management 44, 137-142.

UN General Assembly, 2015, Transforming our world: The 2030 Agenda for Sustainable Development.

Ungson, G. R., and R. M. Steers, 1984, Motivation and Politics in Executive Compensation, Academy of Management Review 9, 313-323.

Walker, K., and F. Wan, 2012, The Harm of Symbolic Actions and Green-Washing: Corporate Actions and Communications on Environmental Performance and Their Financial Implications, Journal of Business Ethics 109, 227-242.

West, J., and D. Berereton, 2013, Climate Change Adaptation in Industry and Business: A Framework for Best Practice in Financial Risk Assessment, Governance and Disclosure (National Climate Change Adaptation Research Facility, Gold Coast, Australia).

Whelan, T., and C. Fink, 2016, The Comprehensive Business Case for Sustainability.

Wilson, M., 2003, Corporate Sustainability: What is it and where does it come from?, Ivey Business Journal.

Winston, A., 2010, Green offers a plan for recovery, Financial Executive (Financial Executives International, Morristown) 23.

- 2017, Whiteboard Session: The Business Case for Sustainability.

Wood, D., and D. G. Ross, 2006, Environmental social controls and capital investments: Australian evidence, Accounting and Finance 46, 677-695.

World Commission on Environment and Development, 1987, Our common future (Oxford Univ. Press, Oxford [u.a.]).

Wyld, D. C., 2010, Executive Stock Options: Still Plenty of Shenanigans?, Academy of Management Perspectives 24, 79-80.

Zammuto, R., 2005, Does who you ask matter? Hierarchical subcultures and organizational culture assessments, The Business School, University of Colorado at Denver.

Zellweger, T., 2007, Time Horizon, Costs of Equity Capital, and Generic Investment Strategies of Firms, Family Business Review 20, 1-15. 